\title{
African therapy for a fractured world(view): The life of founder bishop Johannes Richmond and the invention of tradition and group cohesion in an African Initiated Church
}

Author:
Cas Wepener
Affiliation:
'Department of Practical
Theology, Faculty of
Theology, University of
Pretoria, South Africa
Correspondence to:
Cas Wepener
Email:
cas.wepener@up.ac.za
Postal address:
Private Bag X20, Hatfield
0028, South Africa
Dates:
Received: 27 Jan. 2015
Accepted: 11 Apr. 2015
Published: 26 June 2015
How to cite this article:
Wepener, C., 2015,
'African therapy for a
fractured world(view):
The life of founder bishop
Johannes Richmond and
the invention of tradition
and group cohesion in an
African Initiated Church',
HTS Teologiese Studies/
Theological Studies $71(1)$,
Art. \#2900, 9 pages. http://
dx.doi.org/10.4102/hts.
v71i1.2900
Copyright:
@ 2015. The Authors.
Licensee: AOSIS
OpenJournals. This work is
licensed under the Creative
Commons Attribution
License.

License.
In the book The invention of tradition historian Eric Hobsbawm claims that the process of the invention of tradition serves the formation of group cohesion. The different versions of the life story of the founder bishop of the Corinthian Church of South Africa (AIC), as documented during many years of conducting qualitative field work in this church, are used in this article as a case study in this regard. The article unpacks the way in which the invention of tradition as a process is in this particular AIC currently a work in progress contributing to the formation of a particular type of group cohesion that stretches over racial, religious and denominational boundaries especially by means of the unique liturgical rituals that were influenced by the life story of the founder. The group cohesion that this process fosters is in essence aimed at healing in all its multifaceted dimensions, which includes healing from physical ailments, 'healing' from barrenness, healing from spirit possession to healing as (re-)incorporation of an individual into the larger group, the healing of a nation as well as healing from a dualistic spirit-matter worldview.

\section{Introduction}

The photograph on the next page (Figure 1) is a picture of Johannes Richmond, the founder bishop of the Corinthian Church of South Africa (CCSA). For the past 5 years an international team of researchers has been studying the worship life of the CCSA, an African Initiated Church (AIC) with congregations in the Eastern Cape, KwaZulu-Natal and Gauteng provinces of South Africa. A vast amount of the worship and other rituals performed in this church have been documented and reflected upon, especially in an attempt to better understand the role of these symbolic actions in the generation of social capital (cf. Barnard, Mbaya \& Wepener 2014; Mbaya 2011, 2012; Nell 2009; Swart 2011; Wepener, Mbaya \& Barnard 2011; Wepener et al. 2010). As the research progressed it became increasingly clear that these ritual actions cannot be fully comprehended without taking into consideration the historical roots of the church and especially the life history (biography) of the founder bishop of the CCSA, Johannes Richmond. The life history of the CCSA's founding leader played a vital role in the formation of the unique liturgical rituals to be found in this church, and his life story, or rather stories, are also still exercising that role after his death. The life story of the founder is currently in the process of what can be termed 'the invention of tradition' (Hobsbawm \& Ranger 1983). The tradition that is being invented is closely connected to the life story of Johannes Richmond and - in the view of the researcher and based on several years of participatory observation in this denomination the narratives related to his life play a significant role in fostering group cohesion in the CCSA, especially through the unique liturgical rituals that were and still are being influenced by his life story. ${ }^{1}$

In order to illustrate this case firstly the notion of the invention of tradition will be explored, especially as exemplified in the work of Hobsbawm and Ranger (1983) and scholars of liturgy and ritual (cf. Post 1995a; 1995b; 2000; Stephenson 2010) who have applied this concept to the study of liturgy and rituals. The connection between the invention of tradition and the generation of group cohesion will receive particular attention, as will the transformation of society. The life story of Johannes Richmond will then be reconstructed based on informal and semi-structured interviews held with his immediate family and leaders in the CCSA as well as many church members. Finally, the golden threads identifiable in the life story of Johannes Richmond that

1.There arenumerous documented examples of the life stories and ongoing life of these churches, such as Simon Kimbangu, William Wadé Harris, Alice Lenshina and Engenas Barnabas Lekganyane (cf. Jenkins 2011; Oduro et al. 2008) or even the story of Roman Catholic Archbishop Milingo of Zambia (Ter Haar 1992), even though he was not a church founder as the others were. 


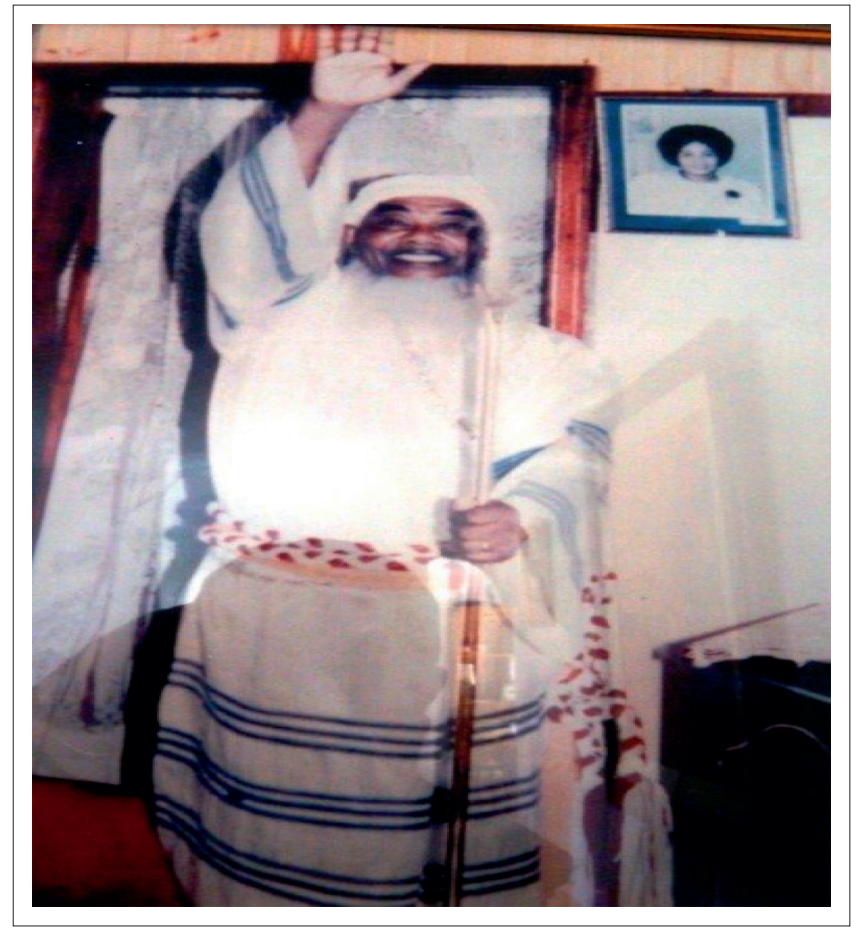

Source: Photo taken by the author.

FIGURE 1: Johannes Richmond, the founder bishop of the Corinthian Church of South Africa (CCSA).

influenced and are still influencing the ongoing story and identity of the CCSA as well as their worship and other rituals will be described and discussed.

\section{The invention of tradition and group cohesion}

According to Hobsbawm, the study of the invention of tradition serves mainly two purposes, it can firstly serve to identify indicators of problems which might otherwise be difficult to identify and, secondly, it sheds light on human relations of the past and specifically the use of history 'as a legitimator of action and cement of group cohesion' (Hobsbawm 1983). In this article the focus will be especially on the latter. Hobsbawm also indicates that the invention of tradition occurs particularly where a rapid transformation of society is taking place. Therefore, the notion of the invention of tradition will now be introduced and then the concept of group cohesion, in particular in relation to ritual and liturgy; this will be followed by a brief look at transformation in South African society in the period under discussion, broadly speaking from the middle of the 20th century to the present day.

\section{The invention of tradition}

In 1983 British historians Eric Hobsbawm and Terence Ranger published a collection of essays under the title The Invention of tradition. The definition Hobsbawm (1983) provides for 'invented tradition' in this book is that it is:

$[A]$ a set of practices, normally governed by overtly or tacitly accepted rules and of a ritual or symbolic nature, which seek to inculcate certain values and norms of behaviour by repetition, which automatically implies continuity with the past. (p. 1)

Further, it is 'essentially a process of formalization and ritualization' (Hobsbawm 1983:4). This definition clearly shows the potential value of this concept for the study of ritual and liturgy. According to Hobsbawm, historians can trace this process at all times and places, but it occurs more frequently 'when a rapid transformation of society weakens or destroys the social patterns for which "old" traditions had been designed' (Hobsbawm 1983:4). Within this process references to the past or history are used to legitimise action, and they also function with regard to maintaining group cohesion (Hobsbawm 1983:12) as well as investing symbols such as flags or dress, rituals, public marches and texts such as songs with significance in creating a particular tradition.

The existence of this process of invention of tradition is most probably easier to identify retrospectively, such as TrevorRoper's (1983) example of the invention of the Highland tradition of Scotland in the same volume, in other words in cases where this process of invention has been to a large extent completed or has at least been ongoing for a fairly long period. In this article this process will also be described historically by looking at the life story of a deceased leader of a church, but also at this process as one that is most probably currently at an earlier phase of the process of the invention of tradition and as such a work in progress. It can thus not yet be claimed that a fully developed tradition has been invented, although in the light of Hobsbawm's work it is clear that this process is currently underway in this particular case.

The idea or process of the invention of tradition can, however, easily become just something with which people humour themselves, or with which they actively try and demythologise current traditions by pointing out that they are indeed 'created' or 'invented' and therefore the facts regarding the tradition are not true. One of the famous examples in the church is the invented tradition regarding Martin Luther and his supposed hammering of the 95 theses to the church door in Wittenberg (cf. Stephenson 2010). In this exploration the idea of the invention of tradition will not be used in such a pejorative sense. What is important, rather, is the fact of the existence of this process and also the important role that the life story of Johannes Richmond is currently playing within this process and concomitantly how his personal narrative is influencing symbols, rituals and worship in the CCSA in a particular way. Our observations and investigation of this process in the CCSA affirms Hobsbawm's theory that the process of the invention of tradition serves to enhance the cohesion of a group, in this regard specifically group cohesion within the CCSA. In what is to follow, the life story of Johannes Richmond will be reconstructed by means of information acquired from his family and members of the CCSA as well as data regarding the worship and rituals of this particular church gathered from congregations in KwaZulu-Natal and the Eastern Cape over a period of more than 4 years (2008-2012). A brief reflection on the notion of group cohesion will, however, 
help to better understand what exactly was looked at in this research, specifically as related to ritual and liturgy.

\section{Group cohesion}

The role of rituals and liturgy in transmitting the past into the present has been recognised by Hobsbawm, but scholars of Africa such as Stephen Ellis and Gerrie Ter Haar (2004) have made a similar observation:

Africans, just like other people, act on the basis of repertoires transmitted from the past not only in the form of states or other bureaucratic institutions, but also rituals, language, social structures and so on. Religion, including in its ritual practice, is a key method by which people gain access to memories transmitted in such ways. (p. 184)

They also observe that religion plays a vital role in both remembering and forgetting the past 'in ways that are conducive to present needs' (Ellis \& Ter Haar 2004:184). The real need with regard to this process of remembering and forgetting moulded on the life story of Johannes Richmond will be discussed in detail at the end of this article; at this point the role of rituals in group cohesion will be explored.

The so-called social dimension of rituals and religion is well known and, according to Dutch liturgist Gerard Lukken (1999), ritual is not only aimed at the self, but also the other and is in fact a call to the other to communicate. Various aspects of ritual, such as the way people dress, for example according to Lukken, play a role in the group formation that occurs in ritual performances. There are also various levels on which this kind of ritualisation occurs, for example, in the family, the local congregation and the larger community, but also on a national level. Lukken (1999) also rightly points out that this group formation crosses time boundaries and that the repetition of the ritual also connects us with generations preceding us as well as those to come, given the way that ritual conserves, renews and transmits. In a similar way the South African theologian Dirkie Smit (2004) refers to processes at work in the liturgy, one of which relates to community. In two recent National Research Foundation (NRF) projects in South Africa on social capital formation, in which the distinction between bonding, bridging and linking capital was often made, several researchers referred to the way in which these religious rituals serve processes associated with bonding in the congregations (cf. Cilliers \& Wepener 2007; Wepener 2009b). The process of the invention of tradition discussed in this article - and the way in which it serves group cohesion - occurred and is still occurring in a very specific historical and social context in South Africa.

\section{Rapid transformations of society}

This section is both the easiest and the most difficult section of this article. It is hardly necessary to argue that South African society has undergone rapid transformations over the past 60 years. In this regard one can think of transformations pertaining to the domains of the post-colonial, the post-apartheid period, rural and urban developments, globalisation as well as the religious transformation of traditional African religions to Christianity, to mention only some of the most obvious ones (cf. Wepener 2009a). The fact that there have been and still are rapid transformations is indisputable; but the question of how exactly the process of the invention of tradition that will be described below relates to these transformation processes is much more difficult to ascertain. An attempt at providing an answer will nevertheless be made in the conclusion. However, as Anderson (1996) notes with regard to members of AICs:

Despite the liberation of South Africa in 1994, the majority are still underprivileged, which means inter alia that efficient medical facilities are scarce and expensive. The legacy of apartheid is still keenly felt by the poor and marginalised. (p. 177)

These underprivileged people are also chiefly members of the CCSA, of which Johannes Richmond was the founding bishop.

What exactly these transformations entail is in fact difficult to ascertain, seeing that there is not a straightforward comparison possible between the historical development of the West and that of Africa. And an over-hasty explanation from a Western perspective is also not advisable. So, for example, Stephen Ellis warns against the idea that Africans just live in another phase of historical time, 'one that Europe and America have long outgrown' (Ellis 2009:9). And Gerrie ter Haar, referring to witchcraft, rightly warns against superficial comparisons of, for example, Africa and Europe, based on an evolutionary approach to the passage of time that lacks historical contextualisation and she adds that 'there are many educated Africans who are well versed in Western culture and science but may nevertheless believe in the existence of witchcraft powers' (Ter Haar 2009:14). In short, there are transformations currently happening, but whether they are transformations in the direction of becoming like the West, or going towards where the West has already been before, are open to question.

Within the transformations of society there is a continual attempt to achieve some kind of equilibrium. In this regard and pertaining to the South African political transition, Stephen Ellis (2009) refers to Archbishop Tutu, who recognised this need for equilibrium between people who are destined to live together. This equilibrium is a state that is always longed for in African society and in this regard rituals play an important role. In a research project on reconciliation rituals in an African context, it became clear that all rituals play an important role in either maintaining equilibrium in society or restoring it (cf. Mbiti 1999; Wepener 2009a), and even in sustaining equilibrium between the living and the dead. It is of course part of the holistic African worldview (cf. Anderson 2000; Manala 2012; Van Beek 2012) which Anderson (2000) describes as:

$[A] 11$ things past and present are seen in Africa as a present material-spiritual unity, it follows that in this worldview the 'spirit' (or in a Christian context, the 'Spirit') pervades all things. (p. 145) 
The quest for equilibrium with this particular worldview in mind and the role of rituals in it is important in understanding the role of the life story of Johannes Richmond and the ritualisation it inspires.

\section{The story of Johannes Richmond according to family and followers The life of Johannes Richmond as told by his wife and daughter}

The life story of Johannes Richmond as reported in this first subsection was told to the author of this article as a researcher by his daughter and his widow, Mrs Richmond, at Mrs Richmond's house in Wyebank, Durban, South Africa. The setting is the living room of her house on a warm winter's morning in early July 2011. As interviewer, from where I am seated in the living room, I am only conscious of the presence of Mrs Richmond - who is sharing the information with meand her daughter Ms Jean Richmond being in the house. In the course of the morning I however discover that we were not alone. I summarise roughly in their words what they shared with me.

The father of founder bishop, Johannes Richmond, was a Malay Muslim and his mother a Zulu Zionist Christian. The founder's mother worked for his father as a house worker whom he made pregnant after his wife's death. They had two children together, namely Girly and Johannes, who was the youngest. After the death of the father of her children, Johannes's mother went back to her family in the Vryheid district of the province that was known as Natal back then. She lived there as part of a farming community, raising her two children. Not long after their arrival this single mother went to the community elders for help. The boy Johannes was very ill with a huge boil on his side and as there were no medical doctors around she did not know what to do. The elders decided to put him in a big pot filled with hot water. In the pot the boil burst and young Johannes fell into a faint that lasted for three days. When he woke up, he discovered that he was completely healed, had the gift of speaking in tongues and at the tender age of twelve started to preach and teach God's message in the local community. Because the people in that rural community did not know English, they called a white man to interpret what the boy was saying. The man, however, said that he could not understand the boy, seeing that the boy Johannes was not speaking English. The people of the community then realised that the boy must be speaking in tongues. They then gave him cow's milk and other special food to make him strong again after his long illness and the three days during which he had been unconscious. Young Johannes Richmond soon afterwards also started to lead worship services every Sunday with a small following.

As a young man Johannes returned to Durban where he was born and acquired a job at a company manufacturing wheelbarrows. He could read and write, although he did not attend any school as a child. Back in Durban Johannes started to worship in a church. At this church he prayed for people who were healed. He also prayed over water which members brought to him and, when they used it, it had healing powers. This was also the church that was attended by his wife-to-be. She started to attend that church, because she heard about Johannes Richmond and his ability to heal people. In that church he also prayed for her neck, with which she had problems, and it was healed. During that time the future Mrs Richmond dreamt of Johannes Richmond's father, the Malay Muslim. He told her in the dream that they must sleep under a marriage certificate and he described to her in her dreams the man she was to marry. The description he gave her was a description of his son, Johannes Richmond. And indeed the two got married.

Johannes Richmond continued to heal people through prayer. He prayed and they were healed of, for example, barrenness; they received spouses to marry, and they were healed of various illnesses. People started to believe in him and he started his own church and built one in Ridgeview (currently Chesterville) in 1956. Many people attended his church back then and it constantly grew. According to his family, however, Johannes Richmond was different from Shembe. ${ }^{2}$ To quote Johannes Richmond's daughter:

'Shembe will for example say Shembe is the way. Not us, not my father, my father was sent by God as a prophet and he proclaimed that Jesus Christ is the way. God gave my father the power to heal people without using muti. ${ }^{3}$

Besides being a healer, Johannes Richmond was also known as a prophet. So, for example, he had a nickname that is still well known in the CCSA and a name by which most members refer to him, namely KwaHlabazingane, which roughly translates as 'right to the point', which according to his family is a reference to his prophetic abilities.

The congregation in Ridgeview, however, was vacated from their premises because of development of the land on which their building stood and moved to Umlazi E-Site in about 1979 , the site where the church is still to be found. Since the move in 1979 the church in Umlazi has been the headquarters of the CCSA. The CCSA is a Zionist church and, according to the relatives of Johannes Richmond, the CCSA is one of the few Zionist churches with buildings. The reason is that Johannes Richmond said that you do not worship under a tree, you worship in a building. The first name of the CCSA, back in 1952, was 'The Church of God in Christ'. As the church grew over the years, they changed the name of the church, because they then discovered a church with a similar name in London, England. There was conflict, because they discovered that the teaching of the London church was too different from their teaching. So after they met the people from London, they decided to change their name.

Over the years the CCSA continued to grow with Johannes Richmond as the Archbishop. However, to quote his

2.Isaiah Shembe was the founder leader of the Nazarite Church in South Africa, who made messianic claims and to whom Sundkler (1961), for example, refers as a 'Zulu Messiah'.

3.Muti is a word used for traditional medicine in general in large parts of Southern Africa and can include for example pieces of an animal or plant. 
daughter regarding the person of this successful church leader: 'You know, my dad was not full of pride, even though he gradually became better off financially over the years. He was a kind man who cared for people.'

The founding bishop and first Archbishop of the CCSA, Johannes Richmond, passed away on 19 October 1991 and was buried in Redhill near Durban. After his death the church officials decided to take his son, Moses Richmond, as their new leader. Moses passed away on 14 May 2007. After Moses passed away the church officials decided that Johannes Richmond's widow, Mrs Richmond, should be the new leader and Archbishop, which she is until today.

\section{Contesting stories regarding Johannes Richmond}

The main storyline was told by his wife and his daughter. Mrs Richmond, who is an elderly lady, became tired during the interview, however, and went to her bedroom to lie down for a while and Jean, her daughter, went to the kitchen to make some tea. At that moment the late founder's niece as well as one of his great-grandsons entered the living room unexpectedly and started to talk about Johannes Richmond without the researcher asking for this information. What follows now is a rendition of what was said and what happened there.

The great-grandson immediately started:

'Yes, he was a prophet and knew things before it [sic] happened. Like one time two white kids drowned in a river. The parents said that they would give a reward for whoever finds them. My great grandfather went there; he prayed, went into the water and brought the two kids back.'

In the absence of the founder's wife, his daughter also took the opportunity to embroider on the story after she returned with the tea:

'My father prophesied about a train that will [sic] capsize in KwaMashu at Effingham Station. He said all Corinthians who wear a red ribbon will not be hurt. Not one Corinthian was hurt, although other people did get hurt and it happened exactly as he prophesied. Even the magistrate called him in to ask how he knew that this will [sic] happen, and he said that God revealed it to him.'

The last comment inspired the founder's niece also to make a contribution building on the previous one:

'Yes, there was second train too; I was in that train myself. This time we had to wear Nazareti ${ }^{4}$ and a red checked ribbon to be saved. Yes, it happened again and everyone was talking about it and it was in the newspapers.'

At that stage another family member, sent by the founder's widow who was still in the bedroom and who obviously overheard the conversation, came to the author and said that Mrs Richmond wanted me to ignore the story about the white kids who drowned; it is not true and the story about

4.Nazarethi is the name for the official dress or uniform of the church worn by members during worship. the train is only true in parts. This took the wind out of the sails of his great-grandson, his daughter and niece.

It was fairly obvious that all relatives present in the living room were ready to provide the researcher with a whole repertoire of additional stories regarding Johannes Richmond and stories pertaining to his prophetic and healing abilities seemed to be particularly popular. What was experienced in Durban prompted the researcher to enquire further into the life story of the founder, which at the time seemed to be a work in progress. More information was obtained from leaders and members from another congregation of the CCSA.

\section{Members of the CCSA in Phepheni, Eastern Cape, on Johannes Richmond}

On the Saturday preceding Palm Sunday in April 2012 individual interviews and a focus group interview were conducted with members of the CCSA congregation in Phepheni, Eastern Cape. Firstly, individual interviews were conducted with the priest and his wife at their home. Afterwards we all went to the church building where members of the congregation also shared what they knew about Johannes Richmond.

The leader of this congregation, Reverend P.W. Dingaan, told the following anecdote:

'I was sick long ago. Then a woman from Phepheni took me to Johannes Richmond. This woman said I must meet Johannes Richmond, because Johannes Richmond was a prophet. Then when we went to Johannes Richmond it was a miracle, because Johannes Richmond told me the story of my life and the cause of my illness. He asked me: "Do you know why you are sick?" And continued: 'It is because they put the muti out for you and also the tokoloshe ${ }^{5}$ to follow you.' And then after he told me this, he first gave me holy water to use, which I drank, I also steamed with [it] and also sprinkled it. ${ }^{6}$ This holy water chased away the tokoloshe. After the holy water he gave me muti to use, but even before the holy water and the muti, he prayed for me. Then after I used the muti I was healed. But Johannes Richmond was also a good preacher. And since he healed me and was a good preacher, I joined the church.'

Mrs Dingaan (who obviously could not wait to join in and share more about Johannes Richmond):

'Yes, and he used to visit prisoners and then he prayed hard. After he prayed the people were freed from the prison. This was just like what happened to Peter in the Bible.'

\section{Reverend Dingaan:}

'The other day there was a train in Mlazi, then Johannes Richmond told his congregation that tomorrow there will [sic]

5.There are various descriptions of the so-called tokoloshe; generally it is described as a dwarf-sized, very malevolent character with large genitalia that harasses people at a dwarf-sized, very malevolent character with large genitalia that harasses people at night. So for example some people will put their beds
higher so that the tokoloshe cannot get onto the bed.

6.For an article on water rituals in this congregation and denomination (cf. Wepener \& For an article on water rituals in this congregation and denomination (cf. Wepener
\& Muller 2012). The members sometimes heat the water, and then hold their heads \& Müller 2012). The members sometimes heat the water, and then hold their heads
over the container with the water with a cloth over their heads so that they can inhale the steam. 
be a train accident. Therefore all members who will be using the train must all be carrying their church tickets. ${ }^{7}$ Then really the following day there was a train accident, a head-on collision in Mlazi, but none of the members carrying their tickets were affected.'

Reverend and Mrs Dingaan agreed that there were so many miracles that they could tell me about that it would take a very long time to record all of them. We left their house and walked to the church building to join a group of members the researcher could also talk to.

\section{An elderly woman:}

'Johannes Richmond was leader of our church and also a prophet. I heard that he healed a blind person and that there was a guy in prison whom he prayed for and the man just walked out of prison. We call him 'Hlabanyihlangana' and the evil spirits depart when he is around and therefore we use this name for him.'

I asked who knew this story that was just told and in the group of twelve persons all knew the story and also the nickname of Johannes Richmond.

A middle-aged woman proceeded: 'Johannes Richmond's parents were staying on a farm where all people just mixed: Indians, Blacks and others, and that is where they met each other.' (On the way back in the car my interpreter Nomkosasana had many questions regarding Johannes Richmond, especially about this farm. I shared with her the family's own version of the story and she exclaimed: 'I knew it! That is exactly what I thought in the first place, there were not such farms in South Africa back then!' Thus, for the interpreter, the idealised multiracial farm in the apartheid years as described by the woman above did not sound plausible at all.)

In general the members in Phepheni knew many stories pertaining to the life of Johannes Richmond, especially stories pertaining to his abilities to heal and his prophecy.

\section{The life story of Johannes Richmond enacted}

From the above narratives it is apparent that the life story of Johannes Richmond is alive in the memory of the members of the CCSA. However, his influence is not only apparent in the stories told about him, but also in the attire of members as well as some rituals.

So, for example, leaders (priests and bishops) of the CCSA model their dress on that of Johannes Richmond. Compare here the photograph of Reverend Dingaan (Figure 2), a priest in the CCSA with the photograph of Johannes Richmond at the beginning of this article. Most priests and bishops in this Christian church wear a fez and even grow a beard, as did Johannes Richmond. On the dress of some

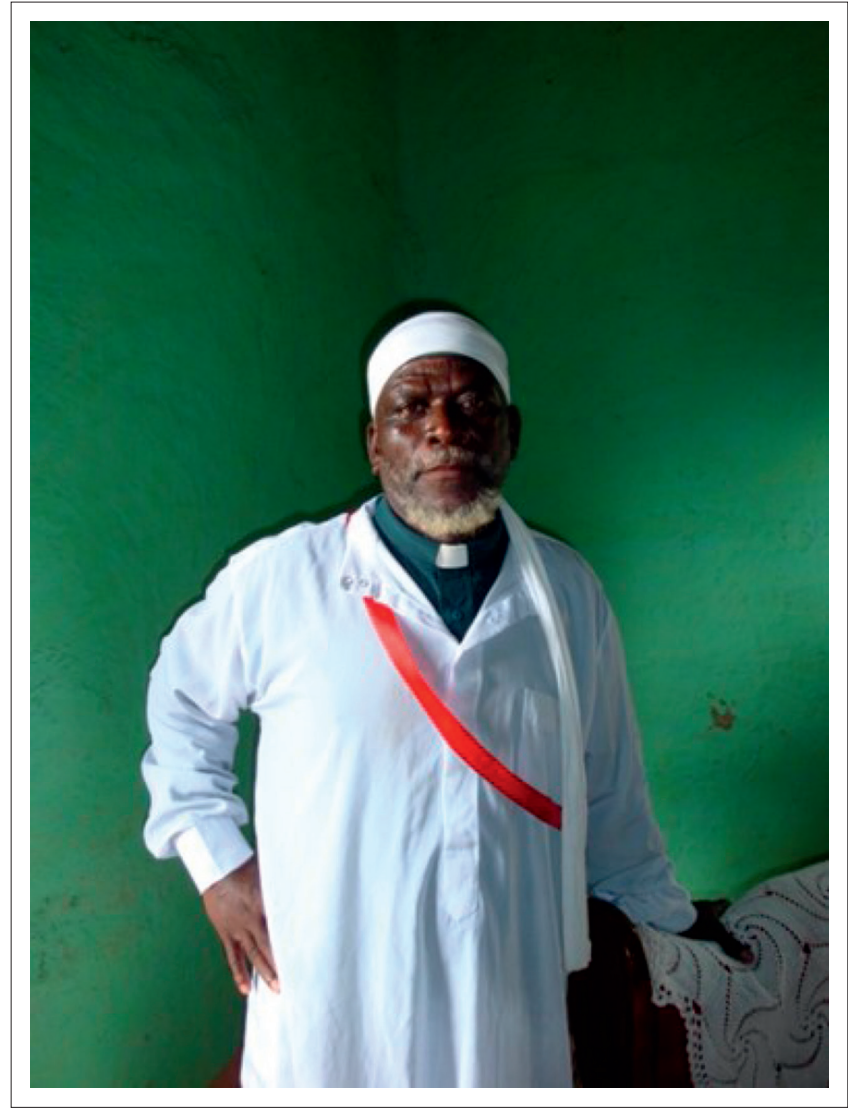

Source: Photo taken by the author.

FIGURE 2: Photograph of Reverend Dingaan, a priest in the Corinthian Church of South Africa (CCSA).

members the Islamic symbolism mixed up with Christian symbolism is also visible for example, a half moon next to a cross. Also the abundant use of Indian incense (agribadi) and shiny clothes in the CCSA as such are, according to his daughter, reminiscent of her father's Malay background. ${ }^{8}$ Lastly Johannes Richmond had, according to his relatives, a preference for the use of the Old Testament. In many rituals such as the isitshisa during which a heifer is sacrificed (cf. $\mathrm{Nm}$ 19) or the various cleansing rituals based on examples found in the book of Leviticus this is apparent. Lastly, it should be mentioned that Johannes Richmond's name is invoked together with the three persons of the Holy Trinity in most (if not all) prayers prayed during worship services in the CCSA.

\section{Johannes Richmond and the group cohesion of the CCSA: A work in progress}

As mentioned earlier, the invention of tradition is, according to Hobsbawm (1983:1-2), 'essentially a process of formalization and ritualization, characterized by references to the past, if only by imposing repetition.' The ritualisation in the CCSA is currently strongly based on the person or

8.The nickname for this particular AIC in KwaZulu-Natal is 'the Golden Church', and most probably pertains to the Indian or Malay influences that are very visible in the church. 
life story of Johannes Richmond, and even the contesting stories about his life presented above attest to attempts to emphasise certain aspects related to being a Corinthian and to Corinthian worship, which is strongly associated with him. In this last section I will revisit the life story of Johannes Richmond in four phases, illuminating major themes in each particular phase and the way in which they influence the rituals and worship of the CCSA; in conclusion I will discuss how these ritualised themes serve to promote a special kind of group cohesion in the CCSA within the transformations of society that the members currently experience.

\section{Birth: Blending in the blood}

The unique genealogy of Johannes Richmond, namely descending from a Malay Muslim and a Zulu Zionist, had and still has a huge impact on the ritual life of the church. There is, for example, a combination of Christian and Islamic symbolism and cultural elements such as the beard and fez worn by the priests and bishops in an attempt to imitate the image of Johannes Richmond. One could also mention the stars and half-moons on the attire which are also depicted on the floor of the headquarters at Mlazi as well as a combination of African Traditional and Malay or Indian customs such as the burning of incense, wearing of gold which is (according to the family) of Indian origin and the slaughtering of sheep and circle dances in the worship service, which are in line with traditional African customs and religion. In the extended Richmond family there are, for example, members whose names may not be mentioned who attend both mosque and worship services of the CCSA. And it is noteworthy how church members are convinced that Johannes Richmond was born and grew up during the apartheid years on an interracial farm, where his parents supposedly met each other.

\section{Childhood and early adulthood: The healed healer}

When briefly recalling some aspects of the life of Johannes Richmond, there are certain aspects of his childhood years and early adulthood that show great similarity with, for example, the life of Jesus, biblical symbolism and accounts of miracles in the Gospels and Acts. So, for example, his mother was not married when she was pregnant with him. His miraculous healing as a child occurred after he fainted for three days and the symbolism of water in that account should not be overlooked (cf. Wepener \& Müller 2012). He started to preach at the age of twelve (cf. Lk 2:42,46) and had the gift of speaking in tongues. There are also the miracle stories that are recounted pertaining to the freeing of prisoners and the healing of a blind man, as well as how members themselves experienced this and claimed that he healed them personally.

When I asked the members in Phepheni 'Why do you attend this church?' they gave two reasons, namely the healing and the music, but most importantly they said it was for the healing. ${ }^{9}$ These observations are in line with Allan
Anderson's (2003) observation regarding leaders of African churches, namely:

Their following is often determined by the extent to which the people perceive the prophet's pronouncements to be utterances of the Spirit and by their ability to demonstrate the power of the Spirit by meeting concrete human needs in times of sickness and affliction and evil disturbances. (p. 180; cf. Ngada \& Mofokeng 2001)

In this regard there is an interesting case of contesting accounts between the information gained from his wife and daughter and from members in Phepheni. According to his family, he healed without muti, whereas Reverend Dingaan claims that he was healed by Johannes Richmond by, amongst other things, the muti he was given by the founder. The role of healing in the CCSA should not be underestimated and Jenkins says that AICs gained strength because of their emphasis on spiritual healing while epidemic diseases were sweeping through Africa (Jenkins 2011). And in the CCSA, just as in other AIC's, a tradition of pilgriming to the headquarters where the founder lived and was the priest, in this case Mlazi, had developed. Anderson (1996; cf. Wepener \& Ter Haar 2013) refers to such places as 'a sort of healing colony'. The weekly worship service also has a fixed place in the service as well as various other liturgical rituals of this church which are aimed at healing, for example, the ritual sacrifices, the ashes of which are used for healing purposes.

\section{Adulthood and later years: Becoming a prophet}

It is clear that Johannes Richmond is viewed by the members of the CCSA as a prophet, a conviction that grew steadily in the minds of members over the years. In this regard Johannes Richmond also over time acquired the title of 'right to the point ${ }^{\prime 10}$ because of his prophetic abilities. In this regard Anderson (1996) shows how African prophets, similar to the prophets in the Old Testament, rise up on the basis of the felt needs of African people. Their prophetic abilities are closely connected to their healing abilities, and prophecy in the CCSA is usually directed at healing. One of Johannes Richmond's great abilities was his ability to reveal the cause of a problem, for example, muti being placed at a house and then the cause of the problem would be removed and healing could come about. To quote Anderson (1996:178): 'Prophecy in Africa also often becomes an extremely effective form of pastoral therapy and counsel' and he calls this kind of prophecy 'diagnostic prophecy'. In the worship life of the CCSA prophecy as well as dreams and visions related to prophecy are a very common phenomenon both during the weekly worship service, but also outside of it.

The authority of a leader such as Johannes Richmond within the African context should not be underestimated and, according to Anderson (1996:176), there is often no perceived contradiction between the authority of such a leader and that of the Bible. From a certain point of view this kind of 10.This is the translation of 'KwaHlabazingane' by church and family members. 
prophecy may sound like an exercise in fortune telling; however, a closer look reveals the fact that these 'prophecies' are very closely related to the needs of the people. So, for example, on a very practical level Johannes Richmond had a vision that the CCSA should annually serve a meal at the end of the Isitsisha service and present gifts to poor blind people from their community (Mbaya 2011). This they have been doing for some years and the custom has continued to the present day. Another importantly felt need by members pertains to healing, which refers to more than just healing of physical ailments, although not excluding these.

\section{Death: The spirit of a Malay-Zulu prophetic healer still ministering to his flock}

After Johannes Richmond died it was the decision of the leaders of the CCSA that his son and after that his wife should succeed him. In a sense he remains a living memory, seeing that a family member remains the Archbishop of the CCSA. Further, all the bishops and priests of the CCSA model their own appearance on what the founder looked like, involving a particular blend of African (Zionist) and Indian (Muslim) features. However, in spite of this physical material level, Johannes Richmond also remains present on a deeper spiritual level. Often members of the CCSA will claim that he appeared to them in a dream and, according to his daughter, he is indeed still alive in people's dreams. So, for example, the call to worship during the weekly worship services of the CCSA is an invocation of the Holy Spirit as well as the spirit of their founder, while priests of the CCSA also cast out evil spirits in the name of their founder bishop. To quote his daughter once more: 'There is no prayer in our church or of individual members without the names of Jesus Christ and Johannes Richmond [being mentioned]', although she made it clear that her father did not claim to be 'the way' as Shembe claims to be, but that he was a prophet of God. A final worship practice that is influenced by Johannes Richmond and which pertains to death is the fact that CCSA members do not eat at funerals. ${ }^{11}$

In this regard the African worldview which articulates the importance of the spirit world should be emphasised (cf. Ellis \& Ter Haar 2004; Mbiti 2008; Ter Haar 2009). Johannes Richmond passed away in 1991, but he is very much alive in the worship practices and lives of the members of the CCSA. The way in which his presence is perceived is in line with the African concept of time and the spirit world as viewed by most AICs. What is quite unique, however, is the way CCSA members conduct funerals, seeing that they are probably one of the only denominations in Africa that do not eat at funerals and for this his family and other church leaders could provide three reasons that were given to them by the founder, namely the fear of contamination by a corpse that will contaminate a living person with death; that all the eating is just too expensive; and that it is wrong to start eating and celebrating during such a sad time. It is clear from these

11.I have just commenced a new research project together with Professors Marce Barnard and Gert van Klinken from the Netherlands on death culture, a part of which will be devoted to funeral rituals in the CCSA. reasons that Johannes Richmond was indeed a leader with sensitivity to both the pastoral and social concerns of his members, such as grief and poverty.

\section{Conclusion}

From these four life phases, four elements ${ }^{12}$ can be distilled of which two are typical of AIC worship in general and two are quite unique. The typical elements are healing and prophecy, while the unique elements are those pertaining to the birth of Johannes Richmond and his own unique genealogy as well as the way in which the CCSA ritualises death. Taken together, these four elements serve to foster group cohesion with regards to very specific transformations that CCSA member's experience, which I will describe briefly as a conclusion.

The two unique elements are elements that also set the CCSA apart from other AICs and which make them very recognisable not only visually but also through their actions pertaining to death within African culture. The two typical AIC features characterise them as still being part of a larger tradition of the AICs. Together the two typical and two unique features which are all embedded in the life story of the founder and are currently being strongly embroidered upon by relatives and members, serve to generate group cohesion in the CCSA and to foster a CCSA and AIC identity which simultaneously binds them and shapes them as the CSSA in particular, but also as an AIC in general. In essence however all four features pertain to healing, even if some do so only indirectly. Apart from the group cohesion within the CCSA as a denomination and the AICs as a nascent movement, the person of Johannes Richmond and the invention processes with regard to his parents and childhood years can all be related to the South African political transformations of the past two decades and an idealised multiracial origin and thus also for the future. Finally, the ways in which the process of inculturation blends African traditional and Christian practices is a way to foster group cohesion amidst complex tensions in South African society, which include tensions between rural and urban and tradition and modernity to name only a few. And in essence this has to do with maintaining a kind of equilibrium (Mbiti 1999) which is closely related to a very broad definition of the concept of healing.

From the fieldwork conducted it became clear that prophecy in the CCSA is almost always aimed at healing, and the notion of healing is also strongly inscribed in the childhood years of Johannes Richmond and so is the ritual way in which they deal with death. This is also how this whole process of the invention of tradition or Johannes Richmond's life as a work in progress relates to the rapid transformations that occurred and are still occurring in South African society, namely that it is a story of healing within a changing context. The life story of Johannes Richmond that was created is the story of a prophetic healer who, as a spirit is also a man

12.A fifth could have been added, namely the succession in the ccsa and the fact that it was the bishop's choice that Johannes Richmond should be succeeded by his it was the bishop's choice that Johannes Richmond should be succeeded by his
son and subsequently his son by his widow, but I deliberately exclude this aspect here, seeing that this is not unknown or particularly unique in this type of church. 
of the Spirit. And in many ways this story is modelled on the story of the Prophet and Healer, Jesus Christ and other healers and prophets from the Bible and a continuity of that calling which is enabled and empowered by the working of the Holy Spirit. The group cohesion that this process fosters is in essence aimed at healing in all its multifaceted dimensions, which includes healing from physical ailments, 'healing' from barrenness, healing from spirit possession to healing as (re-)incorporation of an individual into the larger group (cf. Wepener \& Müller 2012); the healing of a nation as well as healing from a dualistic spirit-matter worldview to a holistic worldview (Ter Haar 2009). One could say that what we find here is healing aimed at the restoration of equilibrium in African society, as John Mbiti (1999) puts it, but not only after the atrocities of apartheid, but also the restoration of equilibrium in the midst of the prevailing fracturing by many forces of a holistic worldview. In this regard Ter Haar (2009) rightly observes that the question of whether these miracles and stories about healing are in fact true or whether they can be proven scientifically can be theologically interesting, but this is in fact quite irrelevant. The important question is how the members experience these miracles and instances of healing. On the basis of this article, as well as other research papers produced in the context of the larger research project (Wepener 2009b, 2013; Wepener \& Müller 2012; Wepener \& Ter Haar 2013), it can be concluded that the life of the founder bishop Johannes Richmond is a prime example of the early phases of the invention of tradition within a context in which rapid changes have occurred and are occurring; but that the kind of group cohesion being fostered by this process is group cohesion, of which the core characteristic is cohesion aimed at the restoration of equilibrium in (South) African society. The Johannes Richmond who is currently being created is a Johannes Richmond whose life story assists members to cope with the changes they experience and helps them to survive in their communities as a group. Johannes Richmond's ongoing life story is that of spiritual healing, of a healing spirit whose legacy remains active in providing 'African therapy' (cf. Anderson 2000) for a fractured world (view).

\section{Acknowledgements Competing interests}

The author declares that he has no financial or personal relationships which may have inappropriately influenced him in writing this article.

\section{References}

Anderson, A., 1996, 'The hermeneutical processes of Pentecostal-type African Initiated Churches in South Africa', Missionalia 24(2), 171-185.

Anderson, A., 2000, 'African spirituality in African Initiated Churches', in P. Ryan (ed.), Inculturation in the South African Context, Paulines Publications Africa, Nairobi.

Anderson, A., 2003, 'African Initiated Churches of the spirit and pneumatology', Word'\& World 23(2), 178-186

Barnard, M., Mbaya, H. \& Wepener C., 2014, 'Burning, blessing and burying: Social capital formation in Churches in South Africa', in W. Gräb \& L. Charbonnier (eds.), The impact of religion on social capital formation and social development in different cultural contexts. Entering the field in an international and interdisciplinary perspective, LITVerlag, Berlin/Münster.

Cilliers, J. \& Wepener, C., 2007, 'Research on liturgy and the generation of social capital in contexts of poverty: A South African exploration', International Journal of Practical Theology 11(1), 39-55. http://dx.doi.org/10.1515/IJPT.2007.4
Dunlap, S.J., 2012, 'Healing', in B. Miller-McLemore (ed.), The Wiley-Blackwell companion to Practical Theology, pp. 33-41, Wiley-Blackwell, Oxford.

Ellis, S., 2009,' South Africa and the decolonization of the mind', Inaugural Lecture, Free University of Amsterdam, Amsterdam.

Ellis, S. \& Ter Haar, G., 2004, Worlds of power: Religious thought and political action in Africa, Hurst \& Company, London.

Hobsbawm, E., 1983, 'Introduction: Inventing traditions', in E. Hobsbawm \& T. Ranger (eds.), The invention of tradition, pp. 1-14, Cambridge University Press, Cambridge.

Hobsbawm, E. \& Ranger, T. (eds.), 1983, The invention of tradition, Cambridge University Press, Cambridge.

Jenkins, P., 2011, The Next Christendom: The coming of global Christianity, 3rd edn., University Press, Oxford.

Lukken, G., 1999, Rituelen in overvloed: een kritische bezinning op de plaats en de gestalte van het christelijke ritueel in onze cultuur, Gooi \& Sticht, Baarn.

Manala, M.J., 2012, 'Healing: An essential core function of the church in African Christianity', Theologia Viatorum 36(2), 267-292.

Mbaya, H., 2011, 'The Socio-practical dimensions of Isitshisa [burning of the heifer] in the Corinthian Church of South Africa', HTS Teologiese Studies / Theological Studies 67(2), 8 pages. http://dx.doi.org/10.4102/hts.v67i2.930

Mbaya, H., 2012, 'Friendships and fellowship: Living Koinonia, martyria and diakonia in the Corinthian Church of South Africa - from the Perspective of Social Capital', HTS Teologiese Studies/Theological Studies 68(2), 6 pages. http://dx.doi.org/10.4102/ hts.v68i2.1169

Mbiti, J.S., 1999, “"Hearts cannot be lent!" in search of peace and reconciliation in African Traditional Society', The Princeton Seminary Bulletin XX(1), 1-12.

Mbiti, J.S., 2008, African religions and Philosophy, 2nd edn., Heinemann, Gaborone.

Nell, I.A., 2009, 'Leaders lost in transition: A case study in leadership, ritual and social capital' Nederduitse Gereformeerde Teologiese Tydskrif 50(1/2), 160-170.

Ngada, N.H. \& Mofokeng, K.E., 2001, African Christian witness: African indigenous churches, Cluster Publications, Pietermaritzburg.

Oduro, T., Pretorius H., Nussbaum, S. \& Born, B., 2008, Mission in an African way: A practical introduction to African Instituted Churches and their sense of mission, Christelike Lektuurfonds (CLF), Wellington.

Post, P.G.J., 1995a, 'De creatie van traditie volgens Eric Hobsbawm', Jaarboek voor liturgie-onderzoek 11, 77-100.

Post, P.G.J., 1995b, 'Zeven notities over rituelen verandering, traditie en (vergelijkende) liturgiewetenschap', Jaarboek voor liturgie-onderzoek 11, 1-30.

Post, P.G.J., 2000, Het wonder van Dokkum. Verkenningen van populair religieus ritueel, Valkhof Pers, Nijmegen.

Smit, D.J., 2004, 'Lex orandi, lex credendi, lex (con)vivendi? Oriënterende inleiding tot liturgie en etiek', Nederduitse Gereformeerde Teologiese Tydskrif 45 , 887-907.

Stephenson, B., 2010, Performing the Reformation: Public ritual in the city of Luther, Oxford University Press, Oxford/New York, NY. (Oxford Ritual Studies Series, 2).

Sundkler, B.G.M., 1961, Bantu prophets in South Africa, Oxford University Press, London.

Swart, I., 2011, 'Religion and social capital research in South Africa: Mapping an agenda in progress', in T. Hjelm (ed.), Religion and social problems, pp. 98-121, Routledge, New York, NY. (Routledge Advances in Sociology Series).

Ter Haar, G., 1992, Spirit of Africa: The healing ministry of Archbishop Milingo of Zambia, Hurst \& Company, London.

Ter Haar, G., 2009, How God became African: African spirituality and Western secular thought, University of Pennsylvania Press, Philadelphia, PA.

Trevor-Roper, H., 1983, 'The invention of tradition: The highland tradition of Scotland', in E. Hobsbawm \& T. Ranger (eds.), The invention of tradition, pp. 15-41, Cambridge University Press, Cambridge.

Van Beek, W., 2012, 'Ritueel, patient en therapie in Afrika: Holisme in genezing', in R. van Uden \& J. Pieper (reds.), Ritualiteit tussen heil en heling, pp. 154-172, Kenniscentrum voor Levensbeschouwing en Geestelijke Volksgezondheid (KSGV), Tilburg.

Wepener, C.J., 2008, 'Liturgy on the edge of tradition', Practical Theology in South Africa 23(2), 313-335.

Wepener, C.J., 2009a, From fast to feast: A ritual-liturgical exploration of reconciliation in South African cultural contexts, Liturgia Condenda 19, Peeters Pers, Leuven.

Wepener, C.J., 2009b, 'Snert. Ritual-liturgical measurements and recipes for social capital', Jaarboek voor rituele- en liturgische studies 25, 229-246.

Wepener, C.J., 2013, 'Liturgical 'reform' in Sub-Saharan Africa: Some observations on worship, language and culture', paper presented for Societas Liturgica 2013, Würzburg, Germany, 03-08 August 2013.

Wepener, C.J., Mbaya, H. \& Barnard, M., 2011, 'Worship in the Corinthian Church (AIC), in Phepheni, Eastern Cape, South Africa', Studia Liturgica 41(2), 252-273.

Wepener, C.J. \& Müller, B.A., 2012, 'Water rituals as a source of (Christian) life in an African Independent Church: To be healed and (re)connected', Studia Liturgica $42(1 / 2), 255-269$.

Wepener, C.J., Swart, I., Ter Haar, G. \& Barnard, M., 2010, 'The role of religious ritual in social capital formation for poverty alleviation and social development: Theoretical and methodological points of departure of a South African exploration', Religion \& Theology 17(1/2), 61-82. http://dx.doi.org/10.1163/157430110X517924

Wepener, C.J. \& Ter Haar, G., 2013, 'Sacred sites and spiritual power: One angel, two sites, many spirits', in P. Post, P. Nel \& W. van Beek (eds.), Sacred sites, contested grounds. Explorations in Africa and Europe, pp. 89-104, Africa World Press, Trenton. 